point, and the discovery of another invaluable spring of fresh water is the result. Recently we have had many discoveries to record, all tending to encourage the search for underground water, on the supply of which the pastoral industry of this district so much depends; but none has been of more value to the discoverers or has tended more to encourage others to persevere in spite of difficulties. This latest discovery was made last week in the conntry known as the Pack-Saddle, forming the western portion of Messrs. Donelly and Co.'s Gnalta run. The well was started in the summer of $188 \mathrm{I}$, but had to be abandoned some time after for want of water for the use of the men, and Mr. Donelly was urged to choose another site. He persisted, however, in continuing the original work as soon as surface water was available, and he has now come upon a practically inexhaustible spring. The flow was cut at 272 feet in a properly slabbed 6 feet $\times 3$ feet shaft, and during the night following the water rose $\mathbf{1} 7 \mathbf{2}$ feet, or within 100 feet of the surface. The discovery is worth every penny of $10,000 \%$, as it renders immediately available a large tract of good country hitherto dry and therefore comparatively useless. There is another fine well on Gnalta, from which 30,000 sheep bave been watered in the dry season, and that discovered last week promises to be as good, if not better."

In my first letter I pointed out as one evidence of the underground water the growth of huge gum trees where there was no visible supply. In a recent number of the Scientific Ameri can it is stated that, on clearing out a well, the owner was surprised to find the bottom covered with a dense mass of fine, fibrous roots, which were traced to a Eucalyptus growing at a distance of fifty yards. The large Eucalypti are trees of remarkably rapid growth, which implies the absorption of large quantities of water. By what subtle sense did that root find out where water could be had, and travel so far to get it? Darwin has shown that there is some kind of irritability in the growing points of plants, and that it is sometimes communicable to distant parts. We shall probably come in time to admit that there is a nervous current in plant, though without visible nerves ; and that this rudimentary system of sensation is accom panied by rudimentary desires, and even by rudimentary ideas, which guide the growing points in their search for the clesired objects.

Birstal Hill, Leicester, January 20

\section{Deafness in White Cats}

THIS subject has been of much interest to me, and otologists as well as evolutionists must feel indebted to your contributor in NATURE of December 13 $_{3}$ Mr. Lawson Tait, for his efforts to determine the cause. May I be peimitted, however, from an otologist's point of view, to draw attention to a possible source of error in conducting researches of this kind when deductions are made, as they were in this instance, from acoustic experiments mainly? I allude to Mr. Tait's method of determining the hearing power of the animal experimented on, namely, his cat, "Old Pudge," and the conclusions that he has drawn from the results obtained; thus he infers that purely "tympanic" deafness, consisting in an entire failure of the transmitting mechanism of the middle ear to respond to aërial undulations of sound, existed in the case of "Old Pudge," because the concussion produced by stamping on the floor could be heard by that animal, whilst the voice was not heard. Abnormal hearing of this kind, I am convinced, by no means establishes the fact that inner ear trouble does not exist, since such deaf-mutes as are believed to be defective in this regard are very sensitive to grave or deep tones-thunder, for example, being painful even to them. Pudge's cochlear (inner ear) functions were believed to be serviceable, inasmuch as he could use his voice; but such evidence cannot be accepted as corclusive, for absolutely dea persons, who have been deprived of both "tympanic" and "cochlear" functions, are yet capable of making noises, and often of learning to speak after a fashion. Another point is also of interest in this connection : the ears of Puclge, it is said, were found to be normal in every respect, both as to their transmitting and perceptive functions, with the exception of the absence of a triangular gap from either tympanic membrane. In reference to this it may be said, in the first place, that it is difficult to understand how the delicate mucous membrane lining the tympanum retained its " normal" condition under such exposure; and, in the second place, these defects could scarcely be the cause of absolute deafness, since it is a well-known fact that quite good hearing often remains in the human stbject where, from disease, much greater loss in the tympanic membrane has been sustained than was found to exist in the hearing organs of Pudge. Altogether it seems probable that in certain white cats great congenital deafness may exist, and that the animal, on finding aërial transmission of sound to be imperfect, comes finally, like man under similar circumstances, to disregard its use entirely, and place its reliance solely on sound that can be felt, as it were. Moreover, is it not probable also that the trouble, in some degree at least, may lie in the perceptive centre of the brain ? $\mathrm{It}$ is a significant fact that in Pudge at least some disease of the nervous centres existed, since he was the subject of epileptic convulsions.

I2, West Thirty-fifth Street, New York, January 3

\section{FURTHER DISCOVERIES IN THE FLORA OF ANCIENT EGYPT'1}

SINCE my last communication on the Flora of Ancient Egypt (NATURE, vol. xxviii. p. IOg) I have made some interesting new botanical discoveries in connection with the mummies of the twenty-first dynasty, found at Deir-el-Bahari in July, I88 $\mathrm{r}$, which I will now describe in some detail; the objects having been forwarded to the Museum of the Royal Gardens, Kew.

In the coffin of the Princess Nzi-Khonsu of the twentyfirst dynasty there was a large number of well-preserved wreaths, in which I found three species of plants of the ancient flora not previously authenticated by specimens. Besicies wreaths of the leaves of Mimusops Schimperi and the petals of Nymphac corulea, already described from examples found on the mummy of Ramses II., there were on the mummy of the Princess Nzi-Khonsu, daughter of Tontonthuti, numerous floral wreaths composed as follows: (I) folded leaves of a willow (Salix safsaf) strung on threads of the leaves of the date palm, and serving as clasps; (2) perfect flowers of the corn poppy (Papaver rhacas); (3) complete flower-heads of a corn flower (Centaurea depressa); and (4) complete flower-heads of a composite (Picris coronopifolia).

The flowers of Papaver rhaas equal in size those of the small form one has an opportunity of seeing in such abundance in the Mediterranean region in the spring months as a weed in cornfields, by roadsides, and on walls. In order to prevent the petals from falling, the flowers were picked in an unopened condition; and in drying in the vault the petals had shrivelled and shrunk up into a ball, to which circumstance is due the fact that in examining the moistened flowers all the inner parts appear before the eyes in a wonderful state of perfection. Not a stamen, not an anther is wanting; nay, one might almost say that not even a pollen-grain is missing. Rarely are such perfect and well-preserved specimens of this fragile flower met with in herbaria. The colour, too, of the petals is maintained in a high degree, as in dried specimens of the present day. It is a dark brown-red, that leaves a deep stain on the paper where the flowers have been soaked. The very caducous sepals were wanting in the flowers examined; but all the peduncles were thickly beset with the characteristic, horizontally-spreading, bristly hairs. The petals are destitute of the dark spot on the claw which is common to many varieties of the species. The naked ovary is shortly obovate in shape, or, in some of the very young flowers, cylindrical, though never so much elongated that one could doubt its belonging to the genuine variety described by Boissier in his "FIora Orientalis." The stigmatic disk is obtusely and broadly conical ; and the rays vary in number from eight to ten. The edge of the stigmatic disk is bordered with orbiculate, auriculate, white appendages incumbent upon it. The anthers are oblong, twice as long as broad, and

I This article was sent by the author, Dr. G. Schweinfurth, to Sir Joseph Hooker, to gether with the botanical objects described therein. The original is in German, and the translation here given is as nearly literal as possible.W. BotTing Hemsley. 
the filaments subulate. The smallness of the flowers $\left(2 \frac{1}{2} \mathrm{~cm}\right.$. in diameter), the broad petals, the red colour, the bristly peduncles, the 8-Io stigmatic rays, the oblong oval anthers, the subulate filaments, \&c., point conclusively to the determination of the plant as Papaver rhaas, var. genuina.

At the present time this species is found nowhere in Upper Egypt, and also appears to be absent from the whole Nile Valley, while it is met with in abundance near Alexandria and on the Mediterranean coast as a weed in cornfields.

The flower-heads of Centaurea depressa, the involucral part of which is 15 to $17 \mathrm{~cm}$. in diameter, belong to a form that is now met with in Persia and Afghanistan; whereas in many countries-Greece, for instance-only small-headed varieties seem to occur. The peduncle served, as in the poppy flowers, to fix the heads in the garlands, which was not always the case in the ancient floral wreaths. ${ }^{1}$ Two or three of the leaves are still left on many of the specimens. They are narrow-linear, almost sessile, and exhibit, besides the arachnoid-canescent pubescence characteristic of the species, the peculiar prickle-like tip, which is several millimetres long, and serves to distinguish $C$. depressa from its only allies $C$. cyanus and $C$. cyanoides. From most of the leaves, however, this brittle appendage has fallen, in consequence of repeated handling of the wreaths. Close under the base of the flower-heads appear some linear bracts, shaped like the upper leaves of the stem. In the ancient specimens these bracts were present in unequal numbers, from two to seven, and often wanting altogether. They do not overtop the whole involucre. This character was rather against the correctness of the identification, for such bracts are not usually present below the heads of $C$. depressa, though they are in $C$. cyanoides, which differs very much in having pappusless achenes. But I have seen a recent specimen (Afghanistan, Griffith, 3294) having one or two leafy bracts at the base of each head. In the recent forms of Centaurea depressa, the lanceolate teeth of the membranous margin of the involucral bracts are sometimes colourless, sometimes brown at the base. In the flower-heads of the twenty-first dynasty these teeth are deep brown in the middle, with a white margin and a white tip, and they are here, as the specific character requires, a little shorter than the breadth of the bract. The three or five teeth at the tips of the bracts are grown together about half their length. On the lowermost bracts of the involucre the teeth are quite decurrent and colourless; on the upper they are more limited in number-from eleven to fifteenand only towards the tip. In consequence of the incautious handling of the wreaths when the coffin was opened, the beautiful ray-flowers, which in this species are exceptionally large, are mostly fallen away. In many heads, however, they are still attached, and exhibit a dark violet colour, similar to recently-dried specimens. The lobes of the limb of the corolla are broad, almost ovate and acuminate. Very well-developed achenes occur in the ancient flower-heads, affording indubitable evidence of the correctness of the determination of the species. The achene is light in colour, shining, slightly lateraliy compressed, and oblong-ovoid in shape. The areole incloses half the length of the achene, and at the base there are a few small hairs, as in recent specimens from Schiraz (Kotschy, 302), Afghanistan (Griffith, 3294), and from Sber (C. Koch), while others from Asia Minor are quite naked. ${ }^{2}$ The intermediate bristles of the pappus are one-fourth longer than the achene, the inner ones half as long. The long prickly tips of the upper leaves, the large, broadly-lobed ray-flowers, and the achene bearing a pappus exceeding it in length, prove that the

I Thus, for example, only flowers of Sesbania agyptiaca with half of the calyx cut off were used.

${ }^{2}$ Hooker, "Fl. Brit. Ind.," iii. p. $3^{85}$, in his diagnosis of the species has " basal areole bearded." flower-heads of the mummy-wreaths belong to Centaurea depressa. This species is wanting in the present flora of Egypt as well as in that of the contiguous countries. It now occurs as a cornfield weed in all parts of Asia Minor, Armenia, Persia, Afghanistan, Beluchistan, and West Thibet; and Prof. Heldreich found it around Tripolitza, in Arcadia, and in the Attic Plain, near Hergellon. In the last-named country the species flowers in April. There are no localities for this plant in Syria and Palestine to my knowledge. Specimens of this Centaurea from ancient Egyptian wreaths are preserved in the museum at Leyden. ${ }^{1}$ It is not stated, however, from what epoch they date.

Many of the wreaths of the mummy of Nzi-Khonsu consist entirely of willow leaves and the flower-heads of Picris coronofifolia, Asch." The numerous features in the parts of the flower-heads which characterise this species are easily seen in the ancient specimens, and not a single peculiarity is apparent by which it might be distinguished from the recent small form with low-spreading branches, now so common on the outskirts of the desert.

The indumentum of the involucral bracts is particularly well preserved. The bracts themselves are long lanceolate with an undulated membranous naked edge, and taper off into a long point; while on the outside along the midrib they are furnished with one to three rows of spreading bristles, glochidiate at the tip, and between these a white arachnoid felt - the same kind of tomentum clothing the peduncles. The achenes of the ray are smooth and cylindrical, more or less curved, as thick at the tip as in the middle, and crowned with a pappus of short persistent bristles cohering about balf their length. The achenes of the disk are broadly club-shaped, somewhat constricted at the tip, and provided between the ten angles with two rows of small round tubercles. The pappus consists of bristles plumose at the tips and is deciduous, and exceeds the achene in length five times.

The dissimilarity of the inner and outer achenes of the ancient Egyptian Picris at once shows that it belongs to the section Spitzelia, Schultz Bip. The smallness of the flower-heads and the nature of the indumentum prove that it belonged to the small desert form, still common about Thebes, and not to the large-headed, otherwise hairy, varieties (Picris lyrata and P. pilosa), only found in the neighbourhood of Alexandria, and on the coast of the Mediterranean Sea. The ultimate inflexion of the involucral bracts over the ripening achenes ("phyllis demum carinatis, incurvis") is perceptible in many of the flower-heads from the ansient wreaths.

Picris coronopifolia belongs to that set of desert plants which are usually only found on the border of the desert as far as the waters of the Nile reach by infiltration. It is not met with in the valleys and channels of the lower desert strips any more than among the weeds which follow cultivation in the black earth of the Nile alluvium. It generally grows associated with Crepis senecioides, Leontodon hispidulum, Picris sulphurea, Lotus pusillus, \&c., which likewise belong to the flora characteristic of the borders of the desert. The flowering time of these plants in Middle Egypt is March and April. In February they only begin to develop, and it may be assumed that the flora of Thebes is from two to four weeks in advance of that of the neighbourhood of Cairo. From the occurrence of the flowers of Picris coronopifolic in the wreaths of the mummy of Nzi-Chonsu we may conjecture that the solemn rites of placing this princess in the vault took place in March or April. The assumption that it tock place in February or May would be doubtful, and it is very

I According to Prof. P. Ascherson in Zeitschrift für Ethnologie, ix. Jahrg., 1877 , and Dr. W. Pleyte in 2 Bylage tot de 35 ste Jaarver-gadering der Ned.-Bat. Vereeniging, 29 Juli, 1882 .

2 Boissier, in his "Flora Urientalis," iii. p. 740 , reduces this species to Crepis radiata $(=C$. senecioides, Del.), and this is done by many other Crepis radiata $(=C$. senecioides, Del.), and this is done by many other
authors. Picris lyrata. Del., and $P$. pilosa, Del., can only be regarded as varieties of $P$. coronopifoiza, Asch. (Leontodon coronopifolizm, Desf.). 
unlikely to have happened in any other months of the year. At Thebes the floral carpet is quite dried up and destroyed as early as April, and in the district of Cairo i's May, so that there would have been great difficulties attending the collection in one day towards the end of April of the large number of flower-heads requisite for the preparation of the wreaths of Nzi-Chonsu. And as far as the other flowers of these wreaths are concerned February to March are the only admissible months. This applies especially to the flowers of the poppy, which even in Alexandria disappear towards the end of April.

If we are able, from our knowledge of the seasons of the present Egyptian vegetation, to limit the interment of a mummy to a short series of months, it follows therefrom the fact, that in the case of the date of the funeral rites attending the placing of a mummy in the final tomb being originally indicated in the inscription on the coffin or elsewhere, light might be thrown on the theoretical determination of the relative Sothis (Sirius) periods. In chronological determinations, which, as far as concerns ancient Egypt, anterior to the time of the twenty-sixth dynasty, are still open to grave suspicion, the aid thus possibly attainable is not to be despised. We know from the hieroglyphical writings, the temple inscriptions and ornamental pictures of the temple, that the ancient Egyptians had a great predilection for their gardens; and we learn from the narratives of their crusades in distant countries that they gave a prominent place to foreign vegetable productions, even in their triumphal processions. Amongst objects met with in the funeral repasts and in the offerings in the tombs there are, moreover, so many products of evident foreign origin, that we cannot be surprised at finding that many of the flowers and leaves employed in the composition of the funerd wreaths and garlands could not have belonged to the native flora of the country, but must have been cultivated expressly for the purpose. This may, then, have been the case with Centaurea depressa, which, like Alcea ficifolia and Delphinium orientale, suggests Western Asia, and especially the countries of the Upper Euphrates. As far as Papaver rhoas is concerned, it may also be assumed that it was cultivated by the ancient Egyptians on account of its brilliantly coloured flowers, although this does not exclude the possibility, independently of any necessity for a change in the climats to have taken place in the interval, that the common poppy was not such an extraordinary rarity in the cornfields of that period as it is at the present time.

Among the mummies of the twenty-first dynasty discovered at Deir-el-Bahari, there may lie hidden a number of plant remains still unknown to me; as a careful search through the coffins, especially as far as those mummies are concerned which are still preserved with their wrappers intact, was for many reasons necessarily postponed. The garlands, particularly, in those coffins, composed as they are of various leaves and flowers, may be expected to furnish many novelties to the ancient flora of Egypt. Among a few fragments of the wreaths of Mimusops leaves and Nymphæa petals that have reached the Natural History Museum of Milan there accidentally appeared a detached corolla of a Jasmine, which may belong to Jasminum sambac, a species still commonly cultivated in Egyptian gardens. The Egyptian Museum in the Cairo suburb of Boulak contains in addition a number of plant remains of authenticated species taken from earlier explorations of tombs that would go to enrich the flora of ancient Egypt.

In the spring of last year Dr. Maspero discovered in the well-known burying-place of Nofert Sekeru, near Sheykh Abdel Gurna, Thebes, an unopened vault of later date, in which was a well-preserved female mummy of the Greco-Roman period. This mummy is swathed from head to foot in wreaths of the leaves of Mimusops, without any flowers. These leaves are larger (eight centi- metres without the peticle), because fully grown, than those in the older garlands. The petioles are broken off short, and the whole construction of the wreaths is of a much ruder and more careless description. Specially interesting in this mummy is a wreath around the forebead composed entirely of the leaves of Olea europaa. These leaves are also folded and threaded edge to edge with the tips directed upwards; but the mode in which they are sewn together is different from the other wreaths, being done by a coarse string of a fibrous material as yet unknown. The Leyden Museum possesses similar funeral wreaths of olive leaves, ${ }^{1}$ and in the Berlin Museum there are some bundles composed of branchlets of the olive tree. Whether the "wreath of justification" mentioned in the obituary of Osiris was such a wreath of olive leaves, or whether under this designation the garlands of Mimusops and willow leaves which encircled the neck and breast of the mummies were intended has not jet been ascertained.

Moreover, Theophrastus, Pliny, and Strabo authenticate the presence of the olive in Upper Egypt. According to Theophrastus (iv. 2, 9) the olive tree grew in the Theban province. According to Strabo (xvii. § 293) olive trees were only found in Fajum and in the vicinity of Alexandria. Now the olive tree flourishes in Lower and Middle Egypt, and very old trees exist in Fajum and in the Oases.

In a special glass case in the Egyptian museum at Boulak is a variety of objects which formed the funeral repasts and offerings in a vauit at Dra Abu Negga (Thebes) of the twelfth dynasty (2200 to 2400 B.C.) Among them are the following vegetable products: grains of barley ${ }^{2}$ and wheat; tubers of Cyperus esculentus; kernels of Mimusops Schimperi; fruits of Punica gravatum, Ficus Carica, Balanites agyptiaca, Hyphane thebaica, Medenia argun; a water-Hask of Lagenaria vulgaris; two cones of Pinus Pinea; a mess of Lens esculenta; two see's of Faba zulgaris, and one seed of Cajanus indicus; a broom made of Ceruana pratensis ; a bowl full of capsules of Linum humile intermixed with pods of Sinapis arvensis, var. Allionii. Among the plants here cited the Linum deserves special consideration, for, notwithstanding our ample knowledge of its cultivation, thanks to the records of the early authors, botanists who have busied themselves with the investigation of the vegetable remains of ancient Egypt have hitherto not been able to determine with certainty the species of Linum cultivated.

Linum capsules of the twelfth dynasty exist in a very good state, together with the calyx and pedicel, the latter two centimetres long. They are all closed, although the seeds appear to have attained perfect maturity. The length of the capsules reaches 8 millimetres, and the breadth 6.75 millimetres; and the seeds are $5 \mathrm{~mm}$. long. The dimensions given are very little inferior to those of the capsule of the Linum, cultivated in Egypt at the pre:ent day. In external cbaracters it is so like the capsule of the flax now cultivated, that one detects no difference at first sight; and it is only after cutting the seed through that one becomes aware of the change wrought in the course of 4000 years. The proportionate size of the seed, which is much narrowed upwards, but above all the numerous long weak hairs which occur on the inside of the partitions of the capsule, leave no doubt as to the ancient flax belonging to the kind exclusively cultivated still in Egypt and Abyssinia, the Linum humile, Mill. (syn. Linum usitatissimum, Linn., var. crepitans, Schübl. and Martens).

Another coincidence in the ancient and modern Linum

I They belong, according to Dr. Pleyte, to a mummy of the time of Osorkon (twenty-second dynasty). See alss De Candolle, "Physiologie," p. 696 .

${ }^{2}$ In this museum is also preserved a bowl containing broken ears of barley of the time of the fifth dynasty ( 3300 to 3500 years B.c.) which was found near Sashara. 
cultivation is the presence among the ancient capsules of numerous seed-vessels of a species of mustard which is still the commonest and most flourishing weed in every flax field in Egypt. The pods of mustard are almost spherical in shape with a long point, and are seated on pedicels a little less than half the length of the whole pod. Judging from the shape describet, the pods must belong to one of the two varieties, common in Egypt, of Sinapis arvensis, Linn., namely, S. Allionii, Jacq., and $S$. turgida, Del., for the common form of this species is distinguished by elongated pods. As the two varieties named can only be distinguished from each other with certainty by the degree of cutting of the leaves, it would be difficult to decide to which of the two the pods of the twelfth dynasty belong were it not for the circumstance that as $S$. Allionii, Jacq. (characterised by the long-pointed muchdivided leaves), is the prevailing form at the present time in Middle Egypt, a probability offersitself that the ancient pods belong to this form. On the other hand Sinapis arvensis, Linn., var. turgida, Linn., aftects the winter cornfields.

It may be assumed that this species of wild or colonised mustard answers to the Sinapis to which Pliny refers (lib. xix. 54 [8]), as a plant commonly met with under such conditions, and of which he asserts that the Egyptian was the best for yielling oil, and that the Athenians called it Napy, others Thapsi, and others again Saurion.

Lentils, as far as I know, have not hitherto been authenticated from the ancient graves. Pliny (lib. xviii. 31) mentions them as a product of Egypt, where two kinds of them were cultivated. The lentils of the twelfth dynasty appear in consequence of boiling and subsequent shrivelling to have lost a considerable part of their bulk. They are $3 \frac{1}{2} \mathrm{~mm}$. in diameter, while the recent ones average $4 \frac{1}{2}$.

From Ceruana pratensis, a characteristic composita of the banks of the Nile, which has hitherto only been found in Nubia and Egypt, the ancients made those hard hand brooms, still met with in every part of Egypt, and used for sweeping out the houses and especially the privies; for which purposes they are offered for sale in all the markets. The Egyptian department of the British Museum contains a similar specimen.

Furthermore, the two pine cones (Pinus Pinea) noted belong to a species not previously known from the ancient Egyptian relics. Like Parmelia furfuracea and the juniper berries (Funiperus phoniceus), they point to the commercial relations that existed between Egypt and Greece, Asia Minor and Syria. The pine cones which were found in a large basket filled with numerous kinds of fine linen thread, fruits of the Doum palm and a sma!l calabash of Lagenaria, are small and unripe, the scales clinging close together. It is evident that only such of these rare northern exotic fruits as were unsuitable for the table were put in the offerings.

Among objects not previously authenticated from ancient Egypt are the legumes Faba vulgaris and Cajanus indicus. Unger ${ }^{1}$ suggests that the broad bean (Faba) was probably not found in the tombs because it was regarded as unclean. ${ }^{2}$ The two seeds in question were found amongst dried grape-skins and matters of that kind. In shape and relative size they fully correspond to the variety cultivated on a large scale in Egypt at the present day. They are smaller, rounder, and thicker than the European broad bean. ${ }^{3}$ The dimensions of the ancient beans are 10,8 , and $6 \frac{1}{2} \mathrm{~mm}$.

Pliny (lib. xviii. I2 [30]) says of the broad bean that it was used in funeral solemnities; hence the priests ate none, \&c. Perhaps the presence of the broad bean in the offerings of the twelfth dynasty had a meaning similar to that which it had for the Romans.

'Sitzungsberichte der Kais. Akademie der Wiss., Wien., 1859, Band xxxix.

Compare "Herodotus," ii. p. 37.

3 The author most likely alludes to the variety called "field" or "hor sebean" in this country.-W. B. H.
Among the funeral offerings of the ancient Egyptians often occur messes of a pap of roughly cut or coarsely ground grain of barley. They are in small earthen bowls, placed on the floor of the vault like the other offerings. In Prof. Maspero's opinion these messes of barley, which are in no way suitable for human nourishment, answer to the Mola (Mola salsa) offerings of the Romans of earlicr epochs; and I would hazard an explanation of the presence of the broad beans in the offerings of the twelfth dynasty as an example of a possible analogy between ancient Rome and ancient Egypt. For, supposing the correctness of Herodotus's account that the ancient Egyptians regarded the broad bean as unclean, that they ate it in no shape or form, and that their priests could not bear the sight of it, some explanation for its presence must be found. The single seed of Cajanus indicus found with the broad beans in no way differs from the Upper Egyptian variety with yellow flowers. The plant, which is cultivated and wild all over India, as well as in all parts of tropical Africa, is nowhere cultivated in Egypt, though it occurs here and there in a wild state in Upper Egypt. It is certainly one of the oldest cultivated plants in the world, a fact further attested by its discovery in the ancient tombs.

G. SCHWEINFURTH

\section{METAMORPHISM AMONG DEVONIAN ROCKS}

$T H E$ tract of Devonian rocks which stretches through the north of France and Belgium, and across Rhenish Prussia into Westphalia and Nassau, has furnished ample materials for geological disquisition. Among the problems which it presents to the observer, not the least important is the remarkable metamorphism of certain bands or areas of its component strata. Dumont first called attention to this feature in the Belgian Ardennes. It was subsequently shown by Lossen to be extensively developed in the Taunus. More recently the question has been attacked anew with all the appliances of modern petrography. M. Renard has subjected some of Dumont's original localities to a critical revision, which has resulted in a confirmation of the accuracy of that remarkable geologist's observations. The latest contribution to the literature of the subject is a paper (Annales Soc. Geol. du Nord, vol. x. p. 194) by Prof. Gosselet, who at first refused to admit the metamorphism contended for by Dumont and corroborated by M. Renard, but who now comes forward with independent evidence in its support, from another locality. He describes the arkose of Haybes and of Franc-Bois de Villerzies on the frontier of Belgium as having undergone such a metamorphism as to be no longer recognisable. M. Barrois reports that on examining microscopically some sections of the altered rocks, he found among them bi-pyramidal crystals of quartz with liquid inclusions and movable bubbles, as in the quartz of pegmatite. These crystals have been broken in situ, with conchoidal fractures, and the surrounding paste appears as if injected into them. This paste is composed of small irregular quartz-grains like those of schists, and is coloured by fibrous chlorite, so arranged as to impart a more or less schist-like structure. The chlorite, arising from alteration of biotite, is predominant in some specimens, while the quartz-grains preponderate in others. $M$. Barrois compares this altered arkose with some porphyroids and some granitic veins in Brittany recently studied by him. Prof. Gosselet shows that these crystalline intercalations are portions of the true Devonian strata, and he accounts for their highly altered condition by what he terms a metamorphism by friction. A portion of the Devonian rocks has slipped down between two faults and has undergone great lateral pressure, and has in consequence been heated sufficiently that metamorphism has been determined in it. The extent of change has been proportionate to the degree of pressure. The metamor- 